\title{
7 Environmental Impact Calculation
}

To give a short introduction into an environmental impact assessment a hypothetical example will be calcuated as a comparison between two processes. Both of them are designed to fulfill the same job but they take different workstep approaches. Within the environmental impact assessment the focus is on the environmental outcome for every process. The inventory analysis for both processes is shown in table 39.

Table 39: Inventory analysis of both processes (quantity per year)

\begin{tabular}{|l|lll|}
\hline Impact & Unit & Process 1 & Process 2 \\
\hline $\mathrm{CO}_{2}$-eq & $\mathrm{Kg}$ & 582.000 & 300.000 \\
$\mathrm{NMVOC}$ & $\mathrm{Kg}$ & 4.100 & 0 \\
Waste, non hazardous & $\mathrm{Kg}$ & 138.000 & 0 \\
Consumption of non renewable energy* & $\mathrm{MJ}$ & 5.460 .000 & 0 \\
Consumption of renewable energy* & $\mathrm{MJ}$ & 0 & 4.200 .000 \\
COD & $\mathrm{Kg}$ & 0 & 2.600 \\
Consumption of freshwater & $\mathrm{m3}$ & 0 & 62.000 \\
\hline
\end{tabular}

* to keep the example simple one energy source instead of an energymix is assumed

After the inventory analysis is clearly defined each corresponding ecofactor has to be assigned correctly (german ecofactors are used in this example). Throughout a simple multiplication between ecofactor and quantity parameter of the inventory analysis the ecopoints (EP) can be calculated. By repeating this procedure for every impact and adding up of the EPs the final overall environmental impacts of the two processes are optained. The calculation and the results are shown in table 43.

(C) The Author(s) 2018

S. Ahbe et al., The Ecological Scarcity Method for the European Union, AutoUni - Schriftenreihe 105, https://doi.org/10.1007/978-3-658-19506-9_7 
Table 43: Calculation of the ecopoints

\begin{tabular}{|l|llll|ll|}
\hline Impact & Unit & $\begin{array}{l}\text { EF } \\
\text { [EP/unit] }\end{array}$ & $\begin{array}{l}\text { Invent. } \\
\text { proc. 1 }\end{array}$ & $\begin{array}{l}\text { Invent. } \\
\text { proc. 2 }\end{array}$ & $\begin{array}{l}\text { EP } \\
\text { process 1 }\end{array}$ & $\begin{array}{l}\text { EP } \\
\text { prozess 2 }\end{array}$ \\
\hline CO2-eq & $\mathrm{Kg}$ & 15 & 582.000 & 300.000 & 8.730 .000 & 4.500 .000 \\
NMVOC & $\mathrm{Kg}$ & 1475 & 4.100 & 0 & 6.047 .500 & 0 \\
Abfall, non hazardous & $\mathrm{Kg}$ & 7,3 & 138.000 & 0 & 1.007 .400 & 0 \\
$\begin{array}{l}\text { Consumption of non } \\
\text { renewable Energie }\end{array}$ & $\mathrm{MJ}$ & 0,506 & 5.460 .000 & 0 & 2.762 .760 & 0 \\
$\begin{array}{l}\text { Consumption of } \\
\text { renewable energy }\end{array}$ & $\mathrm{MJ}$ & 0,349 & 0 & 4.200 .000 & 0 & 1.465 .800 \\
$\begin{array}{l}\text { COD } \\
\text { consumption drinking } \\
\text { water }\end{array}$ & $\mathrm{Kg}$ & 7010 & 0 & 2.600 & 0 & 18.226 .000 \\
\hline $\mathrm{m}^{3}$ & 22,63 & 0 & 62.000 & 0 & 1.403 .060 \\
\hline
\end{tabular}

The result of both analysed processes is clearly represented in figure 5 as sums of the ecopoints. In addition the influences of the single impacts are to be seen.

In this comparison it is clearly to be seen that process no. 2 shows a higher environmental load with $25.6 \mathrm{mio} \mathrm{EP} / \mathrm{y}$ than process no. 1 with $18,5 \mathrm{Mio} \mathrm{EP} / \mathrm{y}$. The graphic representation provides a deeper insight into the influences of the single impacts for the overall result. Thus this divergent view allows a very specific analytical review of the calculation and the given results. 


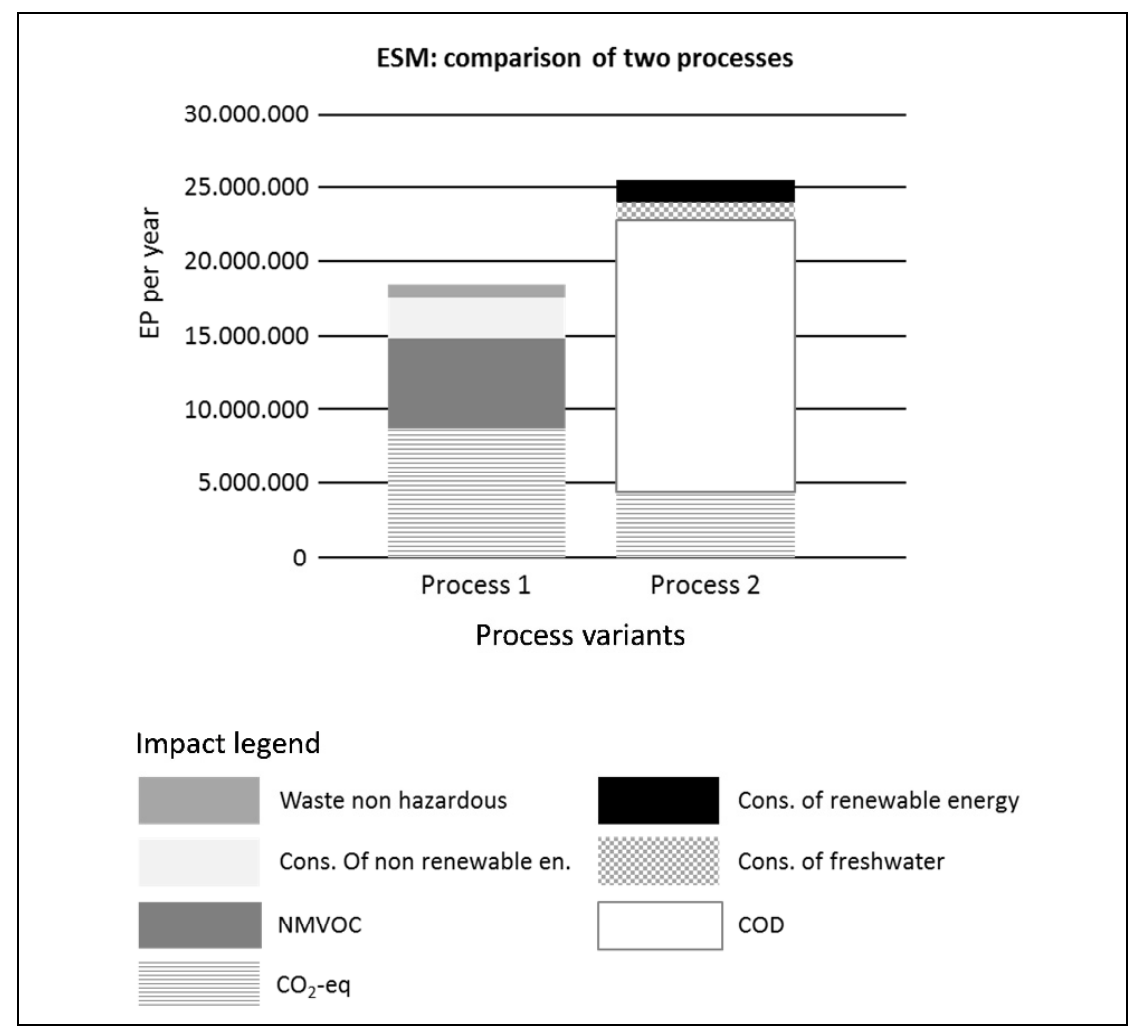

Figure 5: Results

Open Access This chapter is licensed under the terms of the Creative Commons Attribution 4.0 International License (http://creativecommons.org/licenses/by/4.0/), which permits use, sharing, adaptation, distribution and reproduction in any medium or format, as long as you give appropriate credit to the original author(s) and the source, provide a link to the Creative Commons license and indicate if changes were made.

The images or other third party material in this chapter are included in the chapter's Creative Commons license, unless indicated otherwise in a credit line to the material. If material is not included in the chapter's Creative Commons license and your intended use is not permitted by statutory regulation or exceeds the permitted use, you will need to obtain permission directly from the copyright holder.

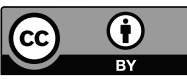

